\title{
PENGEMBANGAN KAIN ENDEK SEBAGAI PRODUK PENUNJANG PARIWISATA BUDAYA DI BALI
}

\section{ENDEK FABRIC DEVELOPMENT AS A CULTURAL TOURISM SUPPORT PRODUCT IN BALI}

\author{
Ni Made Ariani \\ Magister Kagian Budaya Universitas Udayana \\ arianinm7@gmail.com
}

\begin{abstract}
Bali Island as a tourist destination is known for its natural beauty and cultural uniqueness. The uniqueness and characteristics of Balinese culture are very attractive to both domestic and foreign tourists. This makes Bali continue to explore and develop the potential of culture in the middle of society. The development is carried out to support cultural tourism as a superior program. In the development of cultural tourism, traditional fabrics have not also received attention through development programs. One of the traditional Balinese cloths that continuing to be developed is endek cloth. Endek fabric is a traditional fabric with its type of ikat. Previously endek cloth was widely used as clothing in Balinese religious rituals. The development of endek cloth as a supporting product for cultural tourism in Bali were made this fabric renewed and adjusted to the interests of tourists along the times. The aims of this study is to develop endek cloth with using qualitative methods. The theory that will be used is the theory of commodification and social practice theory. The results of the study include (1) the specialty of endek cloth as a supporting product for cultural tourism in Bali, (2) the process of developing endek cloth untill now, (3) Analysis of the development of endek cloth as a supporting product for cultural tourism both internal and external.
\end{abstract}

Keywords: Development, Featured, Traditional, Cultural Tourism, Renewal.

ABSTRAK
Pulau Bali sebagai tujuan wisata terkenal akan keindahan alam dan keunikan budayanya.
Keunikan dan karakteristik budaya Bali sangat menarik bagi wisatawan domestik dan
asing. Ini membuat Bali terus mengeksplorasi dan mengembangkan potensi budaya di
tengah-tengah masyarakat. Pengembangan dilakukan untuk mendukung wisata budaya
sebagai program unggulan. Dalam pengembangan wisata budaya, kain tradisional belum
juga mendapat perhatian melalui program pengembangan. Salah satu kain tradisional Bali
yang terus dikembangkan adalah kain endek. Kain endek adalah kain tradisional dengan
jenis ikat. Kain endek sebelumnya banyak digunakan sebagai pakaian dalam ritual
keagamaan Bali. Pengembangan kain endek sebagai produk pendukung untuk wisata
budaya di Bali membuat kain ini diperbarui dan disesuaikan dengan minat wisatawan
sepanjang waktu. Tujuan dari penelitian ini adalah mengembangkan kain endek dengan
menggunakan metode kualitatif. Teori yang akan digunakan adalah teori komodifikasi dan
praktik sosial. Hasil penelitian meliputi (1) kekhasan kain endek sebagai produk pendukung
untuk wisata budaya di Bali, (2) proses pengembangan kain endek sampai sekarang, (3)

Jurnal IImiah Hospitality Management 
Analisis pengembangan kain endek sebagai produk pendukung untuk wisata budaya baik internal maupun eksternal.

Kata kunci: Pengembangan, Unggulan, Tradisional, Wisata Budaya, Pembaruan.

\section{PENDAHULUAN}

Pulau Bali memiliki keindahan yang mampu menarik minat wisatawan untuk mengunjunginya. Menurut badan pusat statistic, kunjungan wisatawan mancanegara ke Bali pada Juli 2019 adalah sejumlah 604.943 kunjungan atau meningkat $9.96 \%$ dari bulan sebelumnya atau dikenal dengan month to month (https: //bps.go.id/ diakses pada 05 September 2019). Tingginya jumlah kunjungan wisatawan ke Bali tentu disebabkan oleh berbagai macam factor yang melatarinya seperti keunggulan objek alam, keunggulan objek alam dan sarana prasarana.

Keunggulan objek alam di Bali dapat dilihat dari banyaknya tempat yang memiliki keindahan untuk di kunjungi. Tempat-tempat tersebut terdiri dari pantai, laut, sungai, danau, gunung dan hutan. Semua objek alam yang dimiliki Bali dapat dikatakan sangat potensial untuk dijadikan obyek wisata (Rai Utama, 2016: 150). Objek wisata alam pantai yang terkenal seperti Pantai Sanur dan Pantai Kuta. Dalam setiap pantai pengunjung dapat menikmati suasana yang berbeda.

Apabila pengunjung ingin menikmati nuansa matahari terbit atau sunrise, Pantai Sanur merupakan pilihan terbaik. Demikian pula untuk menikmati suasana matahari terbenam atau sunset, pengunjung dapat mengunjungi pantai Kuta. Kemudian untuk menikmati wisata air seperti snorkeling, parasailing, diving, atau berselancar, pengunjung dapat menikmati di Pantai Tanjung Benoa yang terletak di sebelah Utara Nusa Dua.

Gunung dan danau juga tidak kalah menarik untuk dikunjungi. Sebagai salah satu wilayah yang memiliki gunung berapi aktif, Pulau Bali memang sangat berpotensi mengembangkan daerah wisata pegunungan terutama bagi para pendaki. Pesona Gunung Batur dan Agung tidak dapat diabaikan oleh pengunjung. Kemudian untuk danau, juga memiliki daya Tarik yang tidak kalah mempesona. Danau Batur, Danau Buyan dan Danau Tamblingan adalah beberapa contoh dari danau-danau indah yang ada di Bali (Dinas Pariwisata Provinsi Bali, 2016: 8).

Selain keunggulan objek wisata alam, tidak ketinggalan Pulau Bali juga unggul melalui objek budayanya. Berbagai macam jenis budaya yang dihasilkan masyarakat dalam kehidupan berkesenian membuat Bali menarik bagi wisawatan (Suardana, 2018: 36). Kesenian berupa seni tari seperti tari legong, tari pendet, tari cendrawasih, kecak, dll, seni musik seperti gong kebyar, selonding dll, seni lukis, seni rupa seperti pahatan atau patung khas Bali, seni desain seperti motif pada kain tradisional gringsing, songket dan endek, seni arsitektur dan upacara adat atau keagamaan seperti pernikahan, mepandes atau potong gigi, dan ngaben atau pembakaran mayat.

Khususnya dengan keunggulan bidang budaya yang dimiliki, Bali mampu mengembangkan pariwisata budaya. Menurut Nafila (2013), pariwisata budaya merupakan jenis pariwisata yang akan dipandu atau didampingi untuk mengenal sekaligus memahami budaya dan kearifan pada masyarakat local tersebut. Dalam pariwisata budaya, kunjungan dapat dilakukan pada tempat bersejarah, representasi nilai dan sistem hidup masyarakat local, seni, dan segala hal yang menyangkut keunikan dan kekhasan dari masyarakat asli atau local. 
Kekhasan dan keunikan masyarakat lokal yang ditonjolkan oleh pariwisata budaya tentu tidak terlepas dari peran meraka dalam menjaganya. Goeldner (dalam Nafila 2013) menyatakan bahwa pariwisata budaya dalam perkembangannya memiliki kaitan erat dengan apresiasi dari masyarakat untuk terus-menerus menjaga dan memelihara aset budaya atau pusaka yang dimiliki. Dalam pengembangan pariwisata budaya, paling tidak ada empat elemen yang harus terpenuhi untuk mewujudkan pariwisata budaya yaitu akses pariwisata, asset-aset budaya, konsumsi produk/hasil karya dan wisatawan budaya. Ketika keempat eelemen tersebut terpenuhi, maka pariwisata budaya dalam suatu wilayah dapat berkembang pesat.

Beberapa objek penting yang termasuk dalam pariwisata budaya menurut Mappi adalah adanya upacara yang memiliki keunikan dari masyarakat lokal, tarian tradisional, music tradisional, acara pernikahan yang khas, pakaian adat, kain tradisional, bangunan bersejarah, festival budaya, serta adat-istiadat lokal lainnya. Dapat dikatakan semua objek yang disebutkan oleh Mappi telah dimiliki oleh Bali. Salah satu contohnya adalah kain tradisional. Kain tradisional Bali berupa kain tenun masih lestari dan dapat ditemui dengan mudah hingga saat ini.

Tiga jenis kain tenun tradisional Bali yang terkenal yaitu kain gringsing, kain songket dan kain endek. Ketiga kain tersebut merupakan warisan turuntemurun dari masa kerajaan. Kain gringsing adalah kain jenis ikat ganda yang memiliki fungsi sakral terutama bagi masyarakat pengampunya yakni di Desa Tenganan Pegringsingan. Kemudian untuk kain songket, penggunaannya banyak digunakan pada kalangan raja dan keluarganya termasuk di lingkungan istana. Terakhir, kain endek atau yang merupakan kain tenun ikat yang digunakan untuk pakaian masyarakat dalam kegiatan sehari-hari maupun upacara keagamaan (https://tetamian.com/ diakses pada 07 September 2019).

Kain endek memiliki tempat istimewa dihati masyarakat karena penggunaannya tidak terbatas pada upacara keagamaan maupun kalangan istana. Hal tersebut menyebabkan, saat pengembangan pariwisata Bali pada 1930, meskipun dibawah kekuasaan kolonial, kain endek ikut mendapat perhatian. Kain endek mulai dipproduksi untuk kepentingan pariwisata yakni sebagai cinderamata atau buah tangan wisatawan (Picard, 2006: 205). Wisatawan yang datang berkunjung selain menikmati keindahan alam tentu juga dapat membawa kenangan akan Bali melalui kain endek yang dibelinya.

Seiring dengan perkembangan jaman, sejak jaman penjajahan hingga kemerdekaan, kain endek terus mengalami perkembangan. Meski demikian, tentu ada saatnya kain endek mengalami penurunan bahkan dalam keadaan mati suri. Untuk itu, berbagai upaya dilakukan agar kain endek dapat senantiasa lestari. Upaya pengembangan selain untuk melastarikan kain endek, juga sebagai pengenalan terhadap generasi muda agar mereka mengetahui dan dapat ikut serta melestarikan penggunaan kain endek terutama sebagai produk-produk terbaru yang menunjang pariwisata budaya di Bali.

Pengembangan kain endek dievaluasi dengan cakupan pertanyaanpertanyaan seperti: bagaimanakah proses pengembangan kain endek, inovasi apa sajakah yang dilakukan untuk pengembangan kain endek, serta apakah tantangan dan kemudahan dalam pengembangan kain endek sebagai produk penunjang pariwisata budaya. Jawaban atas pertanyaan-pertanyaan tersebut sebagai data untuk merancang kembali pengembangan pengembangan kain endek. Tahapan dimulai dengan melakukan identifikasi terhadap proses pengembangan kain endek yang 
akan dianalisis menggunakan teori komodifikasi yang menjadi daya tarik pengembangan kain endek sebagai produk penunjang pariwisata budaya diformulasi menggunakan teori komodifikasi untuk melihat pengembangan kain endek sebagai produk penunjang pariwisata budaya.

Penelitian ini menganalisis pengembangan kain endek melalui faktor internal dan eksternal. Faktor internal terhadap kain endek mencakup komponenkomponen seperti motif, warna dan harga serta makna filosofi dan kegunaan kain endek. Adapun faktor eksternal kain endek mencakup komponen-komponen seperti pengembangan kain endek dan komodifkasi yang menghasilkan kain endek dengan kemasan menarik. Analisis dilakukan secara sistematis melalui kedua faktor tersebut dan selanjutnya disebut faktor kunci, merupakan keunggulan dari penelitian ini.

Berdasarkan latar belakang yang telah dipaparkan, maka dapat dirumuskan permasalahannya, yaitu: keunikan dan kekhasan apakah yang dimiliki oleh kain endek hingga menjadikannya produk penunjang pariwisata budaya, Bagaimana proses pengembangan kain endek menjadi produk penunjang pariwisata budaya, Faktor-faktor internal dan eksternal apakah yang menjadi daya tarik dalam pengembangan kain endek sebagai produk penunjang pariwisata budaya. Adapun tujuan penelitian ini adalah memahami faktor-faktor internal, eksternal yang menjadi daya tarik pengembangan kain endek sebagai produk penunjang pariwisata budaya di Bali. Kemudian juga sebagai referensi untuk peneliti yang hendak melakukan penelitian sejenis. Sebagai acuan bagi pengambil keputusan dalam menentukan langkah lebih lanjut dalam pengembangan kain endek sebagai produk penunjang pariwisata budaya.

\section{TINJAUAN PUSTAKA}

Penggalian kajian pustaka dilakukan terhadap buku, jurnal, laporan instansi pemerintah dan artikel pada website yang kredibel untuk dapat dijadikan acuan dalam penelitian pengembangan kain endek sebagai produk penunjang pariwisata budaya di Bali.

Buku Pariwisata Budaya dan budaya Pariwisata karya Michael Picard yang memuat tentang perkembangan pariwisata di Bali yang dimulai dari kehidupan masyarakat Bali pada masa kerajaan, kemudian periode masuknya Kolonial Belanda hingga pelaksanaan program Bali Seering sebagai cikal bakal pariwisata budaya di Bali. Kemudian buku ini juga membahas perkembangan pariwisata di Bali sejak masa Kolonial Belanda hingga kemerdekaan. Dalam buku ini juga mencantumkan penggunaan kain endek sebgai produk yang dikembangkan untuk menunjang pariwisata budaya yang telah dicanangkan.

Kemudian referensi juga diperoleh dari jurnal-jurnal yang berkaitan dengan pengembangan kain endek serta pariwisata budaya seperti Analisis Strategi Pemasaran Kain Endek Bali Sebagai Industri Pariwisata Kreatif oleh Deanisa Hakika Putri yang menyatakan beberapa strategi yang dapat digunakan untuk pemasaran kain endek adalah mempertahankan kualitas kain endek, perajin aktif mengikuti berbagai pameran, menggunakan system distribusi secara langsung, melakukan renovasi pada ruang produksi yang dirasa tidak nyaman, bekerja sama dengan pemerintah, mencantumkan harga pada setiap produk, membuka galeri atau 
cabang lain untuk memudahkan pelanggan mendapatkan produk secara lebih dekat dan mengoptimalkan penjuaan melalui media internet atau sosial media.

Jurnal Pemanfaatan Endek Sebagai Sepatu Guna Menarik Minat Generasi Muda Melestarikan Budaya Bali karya I Dewa Gede Ari Darmayoga dkk menyatakan penggunaan kain endek di Bali masih dianggap kuno dan ketinggalan jaman.meskipun harga kain endek dan kain lainnya tidak jauh berbeda, tetapi kecenderungan konsumen akan memilih kain lain yang dianggap lebih menarik, mudah, praktis dan lebih murah. Kecenderungan seperti ini jika terus dibiarkan maka tidak mengherankan apabila jika keadaan tersebut terus dibiarkan kain endek akan menghilang secara perlahan. Hal inilah yang melatarbelakangi penulis untuk membuat kreasi produk baru berupa sepatu berbahan kain endek. Sepatu dipilih karena benda ini merupakan produk yang penggunaannya tidak dapat diabaikan dalam kehidupan sehari-hari. Permintaan pasar akan sepatu juga masih dikatakan tinggi. Hal tersebut kemudian menjadi peluang usaha baru yang memiliki potensi untuk dikembangkan. Melihat kondisi kain endek yang semakin menurun dan adanya peluang untuk membangun bisnis yang saling menguntungkan.

Jurnal Mengelola Warisan Budaya Sebagai Produk Pariwisata oleh I Gusti bagus Rai Utama menjelaskan ide untuk pemanfaatan warisan budaya atau yang dalam Bahasa Inggris disebut cultural heritage baru dikembangkan sejak thaun 1990-an. Tujuan pengembangan wisata warisan budaya adalah untuk pemenuhan pengalaman baru bagi wisatawan dalam menikmati tempat wisata. Pola pendekatan yang dapat digunakan adalah pendekatan produk dan pemasaran. Pendekatan produk dan pemasaran harus dilakukan secara berimbang dengan pelestarian dan pengelolaan komoditas warisan budaya

Konsep pengelolaan memuat dua perbedaan mendasar yang sulit dilakukan dengan seimbang. Kedua prinsip tersebut adalah pengelolaan warisan budaya yang cenderung mengarah kepada pelestarain dan pengelolaan wisata warisan budaya yang mengarah kepada penggunaannya sebagai produk pariwisata. Kesulitan lainnya adalah saat konsep pengembang wisata budaya berbeda dengan harapan wisatawan yang akan mengunjunginya. Seringkali terdapat perbedaan dari cara wisatawan dalam merespon warisan budaya dari sebuth tempat. Terdapat wisatawan yang benar-benar peduli pada nilai yang terkandung dalam warisan budaya, namun terdapat pula yang acuh trhadap nilai yang termanifestasi pada sebuah warisan budaya.

Jurnal Pengembangan Pariwisata Budaya dalam Perspektif Pelayanan Publik oleh Tunggul Prasodjo menyatakan wisata budaya belakangan ini sangat diminati oleh wisatawan. Pariwisata budaya menawarkan keindahan objek dan kandungan nilai yang menambah estetikanya. Kelengkapan sarana dan prasarana serta administrasi yang baik menjadi tolak ukur dari pengembangan pariwisata budaya. Pengelolaan administrasi yang baik juga sebagai pelayanan maksimal terhadap kebutuhan wisatawan dan juga sebagai inventarisasi produk budaya yang dikemas dan menjadi penunjang bagi pariwisata budaya.

\section{METODE PENELITIAN}

Metode yang digunakan dalam penelitian ini adalah kualitatif, guna mengidentifikasi faktor-faktor internal dan eksternal kain endek. Penerapan metode 
kualitatif dalam penelitian ini, untuk menganalisis pengembangan kain endek sebagai produk penunjang pariwisata budaya di Bali.

Jenis data penelitian menggunakan data kualitatif untuk menguraikan faktor-faktor internal dan eksternal. Data kualitatif berupa uraian informasi yang diperoleh dari informan, responden, seperti informasi mengenai kain endek, komponen-komponen internal dan eksternal terhadap kain endek. yang digunakan untuk melengkapi penelitian. Sedangkan sumber data primer dan sekunder menjadi acuan dalam proses penelitian ini. Data primer diperoleh secara langsung dari informan dan responden, untuk mengetahui strategi pengembangan yang telah dan sedang dilakukan oleh pihak pengelola. Data sekunder diantaranya berupa artikelartikel yang diperoleh dari publisitas media masa internet, guna melengkapi dan mendukung data primer yang diperoleh.

Teknik penyajian hasil penelitian adalah dengan menyatukan data yang telah terkumpul akan menjadi satu. Proses analisa data merupakan bentuk kegiatan untuk merangkai data-data yang ada sehingga menjadikan data yang telah terkumpul mampu memberikan jawaban atau arti atas pertanyaan penelitian. Proses analisis data dalam penelitian kualitatif terus berlangsung selama dan juga setelah pengumpulan data dilakukan. Proses analisis dilakukan dari tahap awal hingga tahap penarikan kesimpulan hasil penelitian. Sebagaimana bentuk penelitian kualitatif, perolehan datanya meliputi hal yang berupa deskripsi seperti catatan dari penelitian lapangan yang ada didalamnya memuat aspek baik kata-kata maupun tingkah laku manusia. Pada tingkat analisis data, semua data disusun ke dalam pola yang memiliki sifat kesamaan dan juga sifat perbedaan, kategori berdasarkan fase kegiatan, dan ke dalam tema serta sesuai rumusan masalah.

\section{HASIL DAN PEMBAHASAN}

Kain tradisional di Bali sebagai salah satu objek budaya mendapat secara khusus diperhatikan oleh pemerintah. Bali memiliki 3 kain tradisional yang sudah terkenal hingga mancanegara yakni kain gringsing, kain songket dan kain endek. Ketiga kain ini selalu menarik perhatian wisatawan untuk membeli dan menjadikannya cinderamata ataupun sebagai hadiah untuk kolega. Salah dari ketiga kain tradisional tersebut bahkan dijadikan ikon atau identitas kain dari Bali yakni kain endek.

Kain endek merupakan kain yang penggunaannya sudah tidak asing bagi masyarakat Bali. Nama kain endek digunakan karena kain ini harus diam atau dalam Bahasa Balinya disebut ngendek dalam setiap proses pada pembuatannya (www.tetamian.com). Dalam artian, dalam proses pembuatan kain endek, pertama kali benang harus ngendek di bagian pemintalan, selanjutnya benang juga ngendek dibagian pembidangan dan penggambaran motif. Selanjutnya benang kembali ngendek dibagian pengikatan dan pencelupan. Proses akhir yaitu benang ngendek dalam bagian penenunan. Hal inilah yang menyebabkan kain tenun ikat khas Bali disebut dengan kain endek

Motif-motif kain endek di Bali dibuat berdasarkan pengamatan pada kehidupan sosial (www.tetamian.com). Beberapa motif yang digunakan pada kain endek yakni:

a. Motif Gringsing: kain endek motif gringsing adalah motif-motif yang ditiru dari motif kain gringsing produksi Desa Tenganan Pegringsingan, 
Karangasem. Motif seperti: wayang putri, cemplong, patlikur isi, tali dandan, batung tuung, enjekan siap, dingding sigading. Motif gringsing merupakan motif yang paling dikenal masyarakat. Sejak 1950-an motif ini terus eksis hingga sekarang karena keindahannya.

b. Motif wajik: motif wajik merupakan motif yang diaplikasikan pada kain endek dengan corak segiempat terbalik. Motif ini biasanya diaplikasikan pada kain yang digunakan untuk keperluan kamen atau dimodifikasi sebagai rok, pakaian, tas, sandal dll.

c. Motif prada: saat minat masyarakat mulai menurun terhadap kain endek pada 1990-an, Tirta Ray sebagai designer dan juga dosen dari Institut Seni Indonesia membuat desain kejutan untuk masyarakat. Desain kejutan yang dirancang adalah kain tenun ikat atau endek yang menggunakan prada. Endek motif prada hampir sama seperti endek lainnya, hanya saja ditambah motif prada yang berwarna kuning keemasan pada bagian pinggirnya.

d. Motif Flora: motif flora pada kain endek merupakan pengaplikasian wujud tumbuh-tumbuhan pada kain endek. Motif flora yang biasanya dibuat oleh perajin yakni kangkung, tumbuhan merambat, bunga sandat, bunga jepun, bunga pucuk (motif bunga pucuk menjadi ikon endek di Kabupaten Gianyar).

e. Motif Fauna: sedangkan untuk motif fauna, adalah pengaplikasian bentukbentuk binatang pada kain endek. Contohnya hewan angsa, kuda, burungburung, kera, capung, semut dll.

f. Motif Wayang: motif wayang digunakan oleh perajin untuk mengaplikasikan tokoh-tokoh pewayangan dalam epos mahabarata atau Ramayana ke dalam kain endek. Tokoh yang sering digambarkan adalah krisnha yang sering digambarkan berwarna hijau, selain itu juga ada tokoh pewayangan yang lainnya.

g. Motif tradisi: motif tradisi merupakan gagasan dari pemerintah Kabupaten Jembrana untuk mengaplikasikan tradisi mekepung. Tradisi tersebut adalah tradisi balapan kerbau. Makepung dalam bahasa Indonesia berarti berkejarkejaran, dimana dalam tradisi Makepung ini digunakan dua pasang kerbau yang saling berkejar-kejaran guna untuk menjadi pemenang. Tradisi ini awalnya muncul dari kegiatan membajak sawah yang dilakukan secara gotong royong oleh para petani selama musim tanam di sawah. Tradisi mekepung digambarkan dalam bentuk kain. Motif ini khusus digunakan pada seragam pemerintah Kabupaten Jembrana.

h. Motif Patra: motif patra adalah motif ornamen Bali yang diaplikasikan dalam kain endek. Motif patra seperti rerambatan, karang goak, karang boma, Motif ini banyak digunakan pada kain endek dengan warna merah maroon, merah keunguan, merah hitam dll.

\section{Pengembangan Kain Endek di Bali}

Penerimaan angin Barat begitu kencang tentu dapat mengubah kehidupan masyarakat. Sayangnya kemajuan dan kedinamisan masyarakat dalam menerima Budaya Barat tidak diimbangi dengan penyaringan terhadap hal yang pantas dan tidak pantas. Kurangnya pertimbangan dalam memilih bergaya Barat tentu dapat menyebabkan kekeliruan. Seperti dalam pemilihan gaya berbusana ala Barat. Busana ala Barat tentunya disesuaikan dengan pemakaian oleh masyarakatnya. Hal 
yang penting dalam pembuatan pakaian adalah dilihat dari postur tubuhnya. Jika diperhatikan, dari segi postur tinggi tubuh dan besar badan. Orang Barat umumnya memiliki postur tubuh tinggi dan langsing, berbeda dengan perempuan Indonesia yang tidak memiliki fisik dengan tinggi yang tidak sama seperti mereka (Putra, $2007: 81)$.

Mode busana yang berubah dengan cepat dan memiliki berbagai macam bentuk menjadi barang menggiurkan bagi masyarakat terutama kaum perempuan. selain karena perkembangannya yang pesat, melalui busana masyarakat dapat menunjukkan siapa dirinya. Umberto Eco bahkan menyatakan "I speak through my clothes" (aku berbicara melalui pakaianku). Busana yang digunakan dapat membuat suatu pernyataan tentang diri seseorang. Setiap warna, bentuk, motif dan padu padan menampilkan simbol pada diri seseorang (Barnard, $2011 ; 39$ ).

Rendahnya minat masyarakat menggunakan kain terutama endek menyebabkan kain ini berada dalam keadaan yang kritis hingga perlu perhatian penuh untuk pembaharuannya. Sejak diadakannya fashion show batik, banyak pihak yang menginginkan adanya hal serupa untuk kain tradisional Bali. Waktu yang diperlukan hingga 3 tahun lamanya untuk bisa merealisasikan program tersebut seperti Pesta Kesenian Bali. Dalam realisasinya, program pelestarian awalnya tidak hanya menyangkut kain tradisional tetapi semua jenis kerajinan dan produk budaya khas Bali. meski demikian, tampaknya ada usaha-usaha untuk secara khusus melestarikan kain tradisional. Pelestarian ini di lakukan demi tetap ajegnya Budaya Bali.

Pesta Kesenian Bali merupakan program yang pertama kali dicetuskan dan dilaksanakan oleh Gubernur Bali Ida Bagus Mantra. Pelaksanaan Pesta Kesenian Bali pertama kali diaasakan pada tahun 1979 (Yohan Kanayasa, 2017:131). Acara tersebut berlangsung dari tanggal 20 Juni 1979 hingga 23 Agustus 1979. Tujuan dari pelaksanaan Pesta Kesenian Bali adalah untuk memberikan ruang atau wadah bagi seniman untuk menampilkan hasil karya nya. Dalam pameran Pesta Kesenian Bali pertama, perajin kain endek juga diberikan kesempatan untuk berpartisipasi. Meski jumlahnya tidaklah banyak terdapat 3 perajin yang diikutsertakan dalam pameran tersebut. Keikutsertaan perajin endek dalam Pesta Kesenian Bali pertama turut menjadi pemicu meningkatnya minat masyarakat terhadap kain endek.

Sejak tahun 1970-an, pengembangan pariwisata dilakukan dengan gencar. Situasi yang demikian menuntut orang Bali untuk mempromosikan seni budaya mereka. Salah satunya entu melalui kain endek sebagai kain tradisional. Ditambah dengan adanya pesta kesenian bali tahun 1979 membuat puluhan perajin kain endek mulai berproduksi untuk memenuhi permintaan dari kalangan wisatawan maupun dari masyarakat Bali sendiri. Sebelumnya kain ini hanya dikenal sebagai salah satu jenis kain tradisional Bali. Meningkatnya produksi dan permintaan kain endek menyebabkan kain ini kemudian dijadikan lambang atau kekhasan dari pulau bali. kain endek sebagai lambang dari Bali sama halnya dengan batik yang terkenal sebagai kain khas Jawa (picard, 2006 :250).

Meningkatnya pesona endek diperkuat dengan gagasan gubernur Bali Ida Bagus Mantra yang mulai menggunakannya sebagai pakaian. Kain endek yang lazimnya digunakan untuk kamen kemudian diubah menjadi bahan pakaian. Pembuatan kain endek juga dimodifikasi dalam ukuran lebarya agar dapat dibentuk menjadi pakaian. Gubernur Ida bagus Mantra sebagai pelopor penggunaan pakaian berbahan endek (Picard, 2006 : 210). Beliau sering kali muncul dalam acara formal 
tingkat Provinsi dan Kabuaten kota dalam balutan kemeja berbahan endek. Model baju kemeja endek kemudian mulai diikuti oleh kepala dinas dan kepala bagian di lingkungan Pemerintahn Provinsi Bali. pelan tapi pasti, penggunaan kemeja berbahan endek mulai meluas di kalangan staf provinsi dan kabupaten kota di Bali. pada tahun 1980-an, penggunaan kain endek sebagai seragam sudah banyak dijumpai dalam pegawai pemerintahan baik tingkat Provinsi maupun Kabupaten/Kota sebali.

Pengembangan kain endek yang dilakukan oleh Gubernur Bali Ida Bagus Mantra berhasil menarik minat masyarakat dan menyebabkan meningkatkan pesanan. Tahun 1980-an dianggap sebagai puncak kejayaan kain endek. Penyebabnya adalah pada tahun tersebut, pesanan kain endek yang meningkat diimbangi dengan jumlah perajin yang banyak. Hal tersebut tentu menjadikan, pesanan kain endek dari masyarakat dapat dipenuhi secara langsung oleh perajin. Meskipun pada saat itu penggunaan kain endek hanya sebatas pakaian seragam kantor, cinderamata bagi wisatawan dan sebagai pakaian dalam ritual keagamaan, tetapi penggunaannya masih begitu melekat dan permintaannya terus meningkat.

Kemudian, memasuki dekade 1990 hingga 2000-an penurunan pemesanan kain endek mulai terjadi. Secara perlahan, penggunaan kain endek mulai berkurang begitu pula dengan permintaan akan kain tersebut. Semakin hari, masyarakat semakin enggan menggunakan kain endek. Penurunan permintaan kain endek terjadi sebagai akibat semakin berkurangnya perhatian pemerintah terhadap kain tenun endek. Sejak mencanangkan Pesta Kesenian Bali dan penggunaan kain endek sebagai seragam kantor, pemerintah giat memperhatikan kepentingan perajin seperti permodalan, bantuan alat tenun dan pengadaan kegiatan untuk mendukung pengembangan kain endek.

Kenyataannya sejak memasuki tahun 1990-an, dukungan pemerintah dirasakan semakin berkurang. Untuk kegiatan lomba motif kain endek yang biasa dilakukan mulai diganti dengan perlombaan lainnya. Kemudian bantuan pemerintah kepada perajin juga mulai berkurang. Bantuan pemerintah yang masih berlanjut hingga kini hanyalah dalam hal permodalan dan promosi pada ajang Pesta Kesenian Bali. Hal itupun tidak banyak membantu sebab gairah masyarakat terhadap penggunaan kain endek, juga mulai berkurang.

Sejak periode 1990-an hingga 2000-an perajin endek mulai berkurang. Awalnya jumlah terdapat sekitar 100 hingga 200 -an perajin secara drastis juga menurun hingga tinggal belasan. Berkurangnya jumlah perajin endek dikarenakan pesanan kain endek yang semakin sedikit membuat biaya produksi yang lebih tinggi dibandingkan keuntungan. Selain itu, berkurangnya tenaga pekerja menenun, krisis moneter yang terjadi membuat semakin tingginya harga bahan baku berimbas pada harga jual kain endek ikut mengalami kenaikan. Perlahan tapi pasti perajin yang mengalami kerugian mulai berkurang produksinya hingga menutup usahanya.

Pelan tapi pasti, Inisiatif untuk mengembangkan kain endek mulai direalisasikan Selly Fajarini dalam atap Dekranasda Kota Denpasar bersama Disperindag Kota Denpasar (https://www.denpasarkota.go.id// diakses pada 10 September 2019). Dukungan suami dari Selly Fajarini yang menjabat sebagai Walikota Denpasar yaitu Rai Mantra memiliki pengaruh yang besar untuk kelanjutan program pengembangan endek. Langkah awal yang dilakukan adalah kerjasama Dekranasda dan Disperindag Kota Denpasar untuk membuat programprogram yang menunjang pengembangan endek. Pertama kalinya pada tahun 2008 
diselenggarakan event Gajah Mada Town Festival (sekarang disebut Denpasar Festival) yang salah satu acaranya adalah fashion show endek yaitu fashion on the street atau peragaan busana endek oleh 100 orang berasal dari kalangan pelajar dan mahasiswa

Setelah promosi, program pengembangan kain endek selanjutnya adalah himbauan penggunaan seragam berbahan kain tenun endek kepada instansi pemerintahan dan swasta bahkan sekolah, bank, rumah sakit, perusahaanperusahaan yang ada dilingkungan Kota Denpasar. Program dilakukan untuk menghimbau penggunaan seragam berbahan kain endek, Selly Fajarini bersama tim dari Dekranasda dan Disperindag mengadakan audiensi secara langsung bersama Kabag dari dinas dan petinggi-petinggi perusahaan swasta. Audiensi yang dilakukan berhasil membuat himbauan penggunaan seragam berbahan kain endek dalam perusahaan yang ada di Kota Denpasar baik negeri maupun swasta. Untuk mendongkrak popularitas kain endek terutama bagi remaja, Disperindag dan Dekranasda Kota Denpasar kemudian meluncurkan program duta endek. Pemilihan duta endek dilakukan terhadap remaja-remaja yang memliki bakat dan kemampuan dalam bidang permodelan, memiliki wawasan yang luas serta kemauan belajar yang tinggi (http://dutaendek.balidenpasartrading.com/index.php/web/data/2 diakses pada 10 September 2019).

Salah satu upaya yang dilakukan untuk memenuhi pesanan adalah pemberian bantuan berupa alat tenun kepada perajin. Alat tenun diberikan sebagai hibah agar dapat meningkatkan produksi kain endek. Semakin banyaknya promosi yang dilaksanakan tentu akan meningkatkan jumlah pesanan kain endek. Kemudian untuk memperkenalkan kain endek pada tingkat nasional dan internasional adalah melalui pemberian cinderamata. Cinderamata yang sebelumnya erat dengan plakat atau benda kerajinan lainnya kemudian digantikan menggunakan kain endek. Cinderamata adalah barang kerajinan atau dalam bahasa inggris sering disebut handycraft merupakan hasil kreatifitas perajin dalam mengkemas produk-produk yang menarik sesuai budaya suatu daerah.

Pemerintah Kota Denpasar menginginkan adanya sebuah terobosan baru dalam pemberian cinderamata. Sejak pengembangan kain endek, pemberian cinderamata diganti menjadi kain tersebut dengan kemasan yang rapi dan indah bahkan menggunakan kotak yang elegan. Langkah oemberian cinderamata kain endek secara otomatis diikuti oleh instansi seperti Universitas, Bank, Tour and Travel. Penggunaan kain endek sebagai cinderamata dilakukan untuk mendukung program pemerintah dalam mengembangkan kain endek.

\section{Analisis internal dan eksternal kain endek sebagai produk penunjang pariwisata budaya di Bali.}

Analisis internal dan eksternal kain endek menggunakan teori komodifikasi menurut Arjun Appadurai sebagai komoditas yang dapat diubah untuk memiliki nilai ekonomi (Ertman, 2005 : 35) mencakup :

1. Analisis Internal

Analisis faktor internal kain endek sebagai produk penunjang pariwisata budaya meliputi:

a. Warna, Motif dan harga kain endek

Dalam menganalisis faktor internal dari kain endek hal Utama yang perlu diperhatikan adalah warna, motif, dan harga dari kain tersebut. Pertama, dari segi 
motif, telah dijelaskan pada pembahasan berbagai motif yang diiliki oleh kain endek menjadikannya kain yang memiliki beragam keindahan. Selain motif, peran warna yang ditampilkan pun menarik perhatian pembeli karena warna dari kain endek merupakan warna Dalam pewarnaan kain endek, masyarakat Bali banyak menggunakan warna yang berasal dari pewarna alam dan pewarna sintetis. Menurut orang Bali, setiap warna memiliki makna-makna yang ingin diungkapkan. Warna juga memegang peranan dalam penilaian estetis terhadap seseorang. Setiap warna memiliki karakter yang mampu memberikan kesan terhadap pemakainya. Kemudian hal yang paling penting dari faktor internal kain endek sebagai produk penunjang pariwisata budaya adalah harganya yang terjangkau bagi pembeli. Sebagai kain yang penggunannya akrab dikalangan masyarakat, kain endek memang memiliki harga yang jauh lebih murah dibangdingkan kain gringsing ataupun songket. Kain gringsing per lembarnya dapat dihargai mulai dari harga IDR. 600.000 hingga jutaan. Kemudian untuk harga kain songket berkisar harga IDR. 900.000 juga hingga jutaan rupiah. Sedangkan untuk kain endek. harga per kain mulai harga IDR.250.000-IDR.600.000. Hal ini menjadikan kain endek lebih murah dan dapat menjangkau berbagai kalangan wisatawan. Harga kain endek yang jauh lebih murah tentunya menjadi alternative bagi wisatawan menegah ke bawah yang ingin memiliki kain endek khas Bali dengan budget yang disesuaikan.

b. Makna Filosofis dan Kegunaan kain endek.

Kain endek di Bali memiliki berbagai fungsi dalam masyarakatnya. Dalam fungsi sosial, penggunaan kain endek sebagai penutup tubuh atau pakaian pada kehidupan sehari-hari, kemudian dalam kehidupan bermasyarakat kain tenun bukanlah hanya sebatas kain. Lebih dari itu, kain tenun juga sering dipinjamkan antar tetangga guna mempererat jalinan sos ial antar keluarga maupun masyarakat. Kain endek dipinjamkan atau sebagai cinderamata merupakan simbol ikatan tali persaudaraan atau sering disebut menyame braya untuk Masyarakat Bali. Dalam fungsi budayanya, kain endek dipakai sebagai salah satu pelengkap ritual keagamaan. Terdapat kain endek yang khusus digunakan dalam ritual keagamaan seperti kain cepuk dan kain bebali. Penggunaan kain endek adalah saat upacara nelu bulanin atau tiga bulanan, menek kelih, kain yang digunakan saat upacara menek kelih yakni cepuk rangdi. Kain ini berwarna merah menyala. Pewarna merah melambangkan warna darah haid anak gadis. Setelah mengalami haid, anak gadis telah dianggap dewasa sehingga saat upacara menek kelih digunakan kain cepuk rangdi dan ngaben atau pembakaran mayat. Dalam penggunaannya sebagai pelengkap upacara, kain endek difungsikan sebagai pelindung baik yang diupacarai maupun pemimpin upacaranya Kain endek juga digunakan untuk menghias tempat upacara baik di Pura, Desa dan Rumah dan sering pula digunakan untuk pementasan seni.

\section{Analisis Eksternal}

Analisis faktor eksternal kain endek sebagai produk penunjang pariwisata budaya meliputi :

a. Pengembangan kain endek

Pengembangan terhadap kain endek yang dilakukan pada periode 1979 dan 2009 menjadikan kain endek semakin dikenal secara luas oleh masyarakat. Dalam pengembangan tersebut, kain endek otomatis menjadi produk yang diminati. Mulai 
dari penggunaan seragam, promosi, pembentukan duta endek hingga sebagai cinderamata. Segala program yang dilakukan telah mendongkrak popularitas kain endek. Semakin kain endek dikenal, maka semakin tinggi peluangnya menjadi produk penunjang pariwisata budaya di Bali. Penggunaan kain endek sebagai produk penunjang pariwisata budaya telah dimulai sejak pariwisata berkembang di Bali pada 1930-an. Saat itu, produksi kain endek serta kain tenun lainnya dibuat secara besar-besaran untuk cinderamata bagi wisatawan pertama yang dating ke Bali. Kemudian dalam pengembangannya sebagai seragam kantor instansi negeri ataupun swasta pada tahun 1980 menjadikan kain endek sebagai kain identitas dari Pulai Bali seperti halnya kain batik dari Pulau Jawa. Hal tersebut kembali dibangkitkan dalam pengembangan kain endek yang dilakukan Pemerintah Kota Denpasar sejak tahun 2008. Saat ini, kain endek semakin erat dijadikan kain identitas dari Pulau Bali. Sebagai pulau yang mengembangkan pariwisata budaya, kain endek menjadi ikon Bali dalam beberapa event internasional yang diadakan beberapa tahun terakhir seperti APEC pada 2013 dan IMF 2018 (https://www.cnnindonesia.com/gaya-hidup/ diakses pada 15 September 2019) yang bertempat di Nusa Dua Bali. Dalam kedua event tersebut kain endek banyak digunakan tidak hanya oleh delegasi dari Indonesia juga oleh delegasi dari Luar Negeri.

b. Kemasan yang menarik melalui komodifikasi

Dalam pengembangan kain endek, komodifikasi memegang peranan penting. Pernanan tersebut adalah komodifikasi sebagai cara yang digunakan unruk memperbaharui tampilan kain endek agar dapat diterima oleh masyarakat dna disesuaikan dengan perkembangan jaman. Menurut Mosco, komodifikasi adalah proses pengubahan nialai yang terkandung dalam suatu produk terutama bila dilihat dari nilai guna menjadi nilai tukar. Nilai dari produk komodifikasi sendiri ditentukan oleh harga yang telah dibuat oleh produsen. Terdapat kecenderungan semakin tinggi harga sebuah produk, maka kebutuhan individu dan social terhadap produk tersebut sangatlah tinggi. Dalam konsep komodifikasinya, Mosco menyatakan komunikasi sebagai arena potensial dalam terjadinya komodifikasi. Faktor yang menyebabkan adalah kerena komunikasi memiliki pengaruh besar sebagai komoditas. Pesan yang disampaikan melalui komunikasi memiliki symbol dan citra yang memiliki pengaruh atau surplus value (Susanti, 2016 : 217).

Kain endek dapat dikembangkan sebagai produk pariwisata budaya dengan menjadikannya produk kekinian seperti pengembangan kain endek sebagai seragam kantor pada 1980 merupakan titik awal komodifikasi bentuk terhadap kain endek. Sebaelumnya, kain endek hanya digunakan sebagai kamen untuk menutupi tubuh bagian bawah. Dalam perkembangannya, setelah dikembangkan menjadi seragam, tahun 2008, desain kain endek mulai dikembangkan menjadi busana modern. Busana modern seperti gaun malam atau dress, blus, kemeja, blazer, rok celana dan berbagai macam produk kreatif seperti tas, dompet, aksesoris hingga alas kaki seperti sepatu dan sandal. Kain endek yang telah dikomodifikasi menghasilkan produk yang lebih bervariasi. Hal ini tentunya sangat menguntungkan bagi pariwisata budaya di Bali karena wisatawan dapat memiliki kain endek tidak hanya dalam bentuk kamen tetapi juga produk modern yang telah disesuaikan dengan perkembangan jaman. 


\section{KESIMPULAN}

Kain tradisional di Bali sebagai salah satu objek budaya mendapat secara khusus diperhatikan oleh pemerintah. Bali memiliki 3 kain tradisional yang sudah terkenal hingga mancanegara yakni kain gringsing, kain songket dan kain endek. Kain endek merupakan kain yang penggunaannya sudah tidak asing bagi masyarakat Bali. Nama kain endek digunakan karena kain ini harus diam atau dalam Bahasa Balinya disebut ngendek dalam setiap proses pada pembuatannya. Motifmotif kain endek di Bali dibuat berdasarkan pengamatan pada kehidupan social.

Pengembangan kain endek sebagai produk penunjang pariwisata budaya di Bali dapat dilihat dari faktor internal kain meliputi ciri khas dan keunikan yang dimiliki. Ciri dan keunikan kain endek terdapat pada Dalam menganalisis faktor internal dari kain endek hal Utama yang perlu diperhatikan adalah warna, motif, dan harga dari kain tersebut. Selain motif, peran warna yang ditampilkan pun menarik perhatian pembeli. Dalam pewarnaan kain endek, masyarakat Bali banyak menggunakan warna yang berasal dari pewarna alam dan pewarna sintetis.

Menurut orang Bali, setiap warna memiliki makna-makna yang ingin diungkapkan. Warna juga memegang perana. Kemudian hal yang paling penting dari faktor internal kain endek sebagai produk penunjang pariwisata budaya adalah harganya yang terjangkau bagi pembeli. Sebagai kain yang penggunannya akrab dikalangan masyarakat, kain endek memang memiliki harga yang jauh lebih murah dibangdingkan kain gringsing ataupun songket.

Kemudian makna filosofis dan kegunaan kain endek yaitu Kain endek di Bali memiliki fungsi sosial dan budaya bagi masyarakatnya. Fungsi sosial, penggunaankain endek sebagai penutup tubuh atau pakaian pada kehidupan seharihari. Dalam lingkungan masyarakat sekitar, kain tenun bukanlah hanya sebatas kain. Lebih dari itu, kain tenun sering dipinjamkan antar tetangga guna mempererat jalinan social merupakan simbol ikatan tali persaudaraan atau sering disebut menyame braya untuk Masyarakat Bali. Untuk fungsi budayanya, kain endek digunakan sebagai salah satu pelengkap ritual keagamaan. Terdapat kain endek yang khusus digunakan dalam ritual keagamaan seperti kain cepuk dan kain bebali. Penggunaan kain endek adalah saat upacara nelu bulanin atau tiga bulanan, menek kelih, kain yang digunakan saat upacara menek kelih yakni cepuk rangdi. Faktor eksternal juga tidak kalah penting untuk menjadikan kain endek sebagai produk penunjang pariwisata budaya di Bali. Pengembangan terhadap kain endek yang dilakukan pada periode 1979 dan 2009 menjadikan kain endek semakin dikenal secara luas oleh masyarakat. Dalam pengembangan tersebut, kain endek otomatis menjadi produk yang diminati. Mulai dari penggunaan seragam, promosi, pembentukan duta endek hingga sebagai cinderamata. Semakin kain endek dikenal, maka semakin tinggi peluangnya menjadi produk penunjang pariwisata budaya di Bali. Dalam pengembangan kain endek, komodifikasi memegang peranan penting. Pernanan tersebut adlaah komodifikasi sebagai cara yang digunakan untuk memperbaharui tampilan kain endek agar dapat diterima oleh masyarakat dna disesuaikan dengan perkembangan jaman. Kain endek dapat dikembangkan sebagai produk pariwisata budaya dengan menjadikannya produk kekinian.

Sebelumnya, kain endek hanya digunakan sebagai kamen untuk menutupi tubuh bagian bawah. Dalam perkembangannya, setelah dikembangkan menjadi seragam, tahun 2008, desain kain endek mulai dikembangkan menjadi busana modern. Busana modern seperti gaun malam atau dress, blus, kemeja, blazer, rok 
celana dan berbagai macam produk kreatif seperti tas, dompet, aksesoris hingga alas kaki seperti sepatu dan sandal. Hal ini tentunya sangat menguntungkan bagi pariwisata budaya di Bali karena wisatawan dapat memiliki kain endek tidak hanya dalam bentuk kamen tetapi juga produk modern yang telah disesuaikan dengan perkembangan jaman.

\section{DAFTAR PUSTAKA}

Barnard, Malcom. 2011. Fashion Sebagai Komunikasi. Yogyakarta: Jalasutra.

Dinas Pariwisata provinsi Bali. 2016. "Perancangan kawasan Strategis Pariwisata Nasional (KSPN) Bedugul dan Sekitarnya”. Materi Workshop pada 12 Agustus 2016.

Ertman, Martha. 2005. Rethinking Commodification: Cases and Readings in Law and Culture. New York Press : New York.

Nafila, O. (2013). Peran Komuninas Kreatif dalam Pengembangan Pariwisata Budaya di Situs Megalithikum Gunung Padang. Jurnal Perencanaan Wilayah dan Kota, Vol. 24, No. 1, April 2013.

Picard, Michael. 2006. Bali : Pariwisata Budaya dan Budaya Pariwisata. Jakarta : Gramedia

Putra, I Nyoman Darma. 2007.Wanita Bali Tempo Doeloe: Perspektif Masa Kini.Denpasar: Pustaka Larasan.

Rai Utama, I Gusti Bagus. 2016. Keunikan dan Keindahan Alam Sebagai Citra Destinasi Bali Menurut Wisatawan Australia Lanjut Usia. Jurnal Kajian Bali Volume 06. Universitas Udayana.

Suardana, Gede. 2018.The Legend of Balinese Goddeses : Komodifikasi Seni Pertunjukkan Hibrid Dalam Pariwisata Bali. Jurnal Kajian Bali Volume 08. Universitas Udayana.

Susanti, Dede. Analisis terhadap Komodifikasi Tubuh Perempuan dalam Iklan Es Krim Magnum Versi Pink dan Black . Jurnal Komunika Volume 10. No 2. Juli-Desember 2016

Yohan Kanayasa, I Wayan Rolly dkk. 2017. Persepsi Wisatawan Mancanegara Terhadap Penyelenggaraan Pesta Kesenian bali Sebagai Daya Tarik Wisata. Jurnal Destinasi Pariwisata. Volume 05. Universitas Udayana. 